\title{
Peripheral pooling of bronchographic contrast material: evidence of its relationship to smoking and emphysema
}

\author{
A. W. MUSK, BRYAN GANDEVIA, AND F. J. PALMER
}

From the Departments of Medicine and Diagnostic Radiology, Prince Henry Hospital, Sydney, New South Wales, Australia 2000

Musk, A. W., Gandevia, B., and Palmer, F. J. (1978). Thorax, 33, 193-200. Peripheral pooling of bronchographic contrast material: evidence of its relationship to smoking and emphysema. Sixty-six subjects, mainly derived from various occupational groups and one-third of whom admitted to dyspnoea on exertion, have been grouped according to the appearance of their peripheral airways at bronchography with oily propyliodone. Eleven subjects showed marked peripheral pooling of radiographic contrast material, 22 showed mild or moderate pooling, and in 33 peripheral pools were absent. Pooling was not seen in non-smoking subjects. In the group of subjects without pooling, pulmonary function in non-smokers and subjects with a history of smoking was similar. Subjects with marked pooling had a significantly lower pulmonary diffusing capacity (transfer factor) and evidence of loss of pulmonary elastic recoil when compared with subjects with absent peripheral pooling. These results indicate that bronchographic peripheral pooling is associated with the physiological changes of panacinar pulmonary emphysema and suggest that a causal relationship may exist between the organic bronchiolar lesion of pooling and the peripheral parenchymal lesion of panacinar emphysema.

Peripheral accumulations of various radiographic contrast materials up to $5 \mathrm{~mm}$ or so in diameter have been described in antemortem and postmortem bronchograms for several decades. They have usually been described as 'peripheral pools' (Simon and Galbraith, 1953) if smooth-walled and circular, and as 'spiders' (Reid, 1955; Freimanis and Molnar, 1960), or floral forms (Simon, 1958; Duinker and Huizinga, 1962) if irregular in outline. Their pathological basis has variously been ascribed to chronic bronchitis (Christopherson, 1933; Reid and Simon, 1959; Duinker and Huizinga, 1962; Gregg and Trapnell, 1969), centrilobular emphysema (Simon and Galbraith, 1953; I eopold and Seal, 1961; Leopold and Gough, 1963; Duinker and Huizinger, 1962; Nakamura et al., 1969; Heard, 1969; Blumenthal and Greenberg, 1972; Gamsu and Nadel, 1973; Thurlbeck, 1976) or bronchiolectasis (obliterative or otherwise) (Reid, 1955; Wisoff, 1958; Simonsson, 1965). In postmortem bronchograms Reid (1955) and Heard (1969) have shown radio-opaque material pooled in dilated bronchioles whose nor- mal diameter is less than $1 \mathrm{~mm}$. Bronchioles distal to a 'pool' were shown by Reid (1955) to be obliterated, but some filling of terminal bronchioles beyond the dilated area was seen when the radiographic appearance was of 'spiders'. The bronchographic appearance of the affected lung in McLeod's syndrome (Reid and Simon, 1962) is identical. In spite of interest in the radiographic and pathological characteristics of pools and spiders there has been no previous investigation of their functional correlations.

\section{Subjects}

The subjects studied (Table 1) reflect the occupational interests of this unit. Two small but complete occupational groups (painters and welders) were asked to accept bronchography as an addition to comprehensive lung function tests which were being performed on all employees because of a suspected respiratory hazard. In an attempt to assess the prevalence of peripheral pools in subjects with no known occupational 
Table 1 Bronchographic appearance and source of subjects

\begin{tabular}{lccc}
\hline & \multicolumn{3}{l}{ Pooling } \\
\cline { 2 - 4 } Subjects & Absent & $\begin{array}{l}\text { Minimal/ } \\
\text { moderate }\end{array}$ & Marked \\
\hline Control & \multicolumn{3}{l}{} \\
Painters & 17 & 8 & 3 \\
Welders & 4 & 5 & 2 \\
Detergent enzyme workers & 5 & 4 & 2 \\
Cotton workers & 4 & 1 & 0 \\
Exposed to chlorine & 0 & 0 & 1 \\
Hospital inpatients (no & 1 & 1 & 0 \\
$\quad$ occupational hazard) & 2 & 3 & 3 \\
Total & 33 & 22 & 11 \\
\hline
\end{tabular}

hazard, volunteers were sought from a local penitentiary. They gave informed consent and were accepted for the study if they denied current or previous chest disease when asked if they had ever had 'chest trouble'; these 'control' subjects were deliberately not selected on the basis of 'normality'. The remainder of the series, selected in retrospect, comprised patients in the care of the unit in whom both comprehensive lung function tests and bronchography were considered by the physician to be appropriate to their conventional clinical investigation. They had asthmatic or bronchitic symptoms, with some reason-such as haemoptysis or suspected localised bronchial narrowing or dilatation-for bronchography. Patients with specific or localised disorders, such as carcinoma, tuberculosis, or bronchiectasis, were not included. The usual reasons for comprehensive lung function studies, and especially lung mechanics, were the detailed assessment of disability in potential compensation claims referred for this reason and the assessment of the relative contributions of airway and parenchymal disorders where this affected decisions on therapy. Although the series is heterogeneous in origin, the method of selection does not affect the validity of a comparison of physiological findings between groups defined solely on the basis of a particular bronchographic feature, especially as peripheral pools were not found to predominate in those included on account of occupational history, clinical features, or penal servitude.

As indicated by the functional data, the series comprises mostly subjects with evidence of mild or negligible respiratory disease.

\section{Methods}

\section{SYMPTOMS}

Cough and sputum were considered present if a subject admitted to cough or sputum production on most days for as many as three months each $\stackrel{\vec{F}}{+}$ year. A subject unable to keep up with others of $C$ his own age on hills and stairs at an ordinary pace, $\frac{\bar{c}}{\overline{0}}$ or stating that he became short of breath on $\frac{\rho}{\sigma}$ exertion more readily than others of his own age $\propto$ was accepted as having 'dyspnoea'. Subjects were also asked if they had ever had asthma. 'Smokers' were those currently smoking cigarettes. 'Ex-? smokers' had ceased smoking more than three $\vec{\omega}$ months before the study. 'Non-smokers' had nevero regularly smoked cigarettes. No subject smoked $\vec{x}$ only pipe or cigars.

PHYSICAL SIGNS

Discontinuous crackling sounds heard with a $\overrightarrow{0}$ stethoscope on deep inspiration were classified as? 'crackles', and 'wheezes' were recorded if a con- tinuous musical note was heard during expiration $\frac{D}{O}$ A requested cough under observation was graded as loose (productive) or dry by its sound (Hall and $\vec{\varphi}$ Gandevia, 1971).

\section{RESPIRATORY FUNCTION TESTS}

Forced expiratory volume in 1 second $\left(\mathrm{FEV}_{1}\right)$ was recorded using a water-filled spirometer (W. E.D Collins) or an integrated flow device (Virgulto and Bouhuys, 1973).These instruments were calibrated to give comparable results. Values were correctedo을 to BTPS.

Single-breath carbon monoxide diffusing capa city (transfer factor Dico) (Ogilvie et al., 1957: Cotes, 1968) and vital capacity (VC) were measured using a Resparameter Mark IV (P. K Morgan). Washout volume was $600 \mathrm{ml}$, the volume of gas collected for sampling $700 \mathrm{ml}$, and breath 3 . holding time 10 seconds. Inspired gas consisted of CO $0.4 \%, \mathrm{O}_{2} 21 \%$, He $5 \%$, and balance $\mathrm{N}_{2}$. Gaş analysis was by gas chromatography.

Total lung capacity (TLC) was measured in volume-displacement body plethysmograph (Emer $\frac{7}{0}$ son) by the method of Mead (1960). Maximum expiratory flow volume (MEFV) curves were re응 corded in the body plethysmograph using a Fleisch pneumotachograph No. 4 and box volume. Maxi 은 mum expiratory flow at $50 \%$ TLC ( $V$ max $50 \%$ TLC) was measured from the curves. Static defla tion volume-transpulmonary pressure curves wer recorded using plethysmographic volume according to the technique of Milic-Emili et al. (1964a, b) during interrupted expiration from TLC. Trans pulmonary pressure was measured on a Statham differential strain gauge (PM 131 TC). Transpul $\frac{P}{\circ}$ monary pressure at TLC (P stat at TLC) and transpulmonary pressure (relaxed) at TLQ (P stat at TLC (relaxed)) (Colebatch et al., 1973b were taken as the mean of the three highest 
measurements in five separate interrupted deflation manoeuvres. Static deflation compliance $\left(C_{\mathbf{L}}\right.$ stat) was taken as the slope of the volume-pressure curve over the litre above functional residual capacity. Lung volume at transpulmonary pressure of $6 \mathrm{~cm} \mathrm{H}_{2} \mathrm{O}\left(\mathrm{V}_{\mathrm{L}} 6 \mathrm{~cm} \mathrm{H}_{2} \mathrm{O}\right)$ was read from the curve. The conductance of the airways upstream from the flow-limiting segment (Gs) and critical transmural pressure $\left(P_{t m}\right)$ were calculated from maximum expiratory flow static recoil pressure curves over 30 to $70 \%$ of vital capacity (Leaver et al., 1973).

Closing capacity (C closing) was measured using a single-breath oxygen test (Anthonisen et al., 1969-70).

Total pulmonary resistance $\left(R_{L}\right)$ was measured by the method of Mead and Whittenberger, (1952-53).

\section{BRONCHOGRAMS}

Except where the purpose of the investigation required otherwise, unilateral bronchograms were performed. The nose, pharynx, and larynx were anaesthetised topically with xylocaine $4 \%$, and a catheter was introduced into the right main bronchus during $\mathrm{X}$-ray screening. With the subject lying on his right side so as to fill the right upper lobe as selectively as possible, $10-15 \mathrm{ml}$ of oily propyliodone, which is superior to aqueous propyliodone for filling the peripheral bronchial tree, were injected. The upper lobe was chosen to minimise difficulties of interpretation due to chronic bronchitic changes in the lower lobes or to inadequate peripheral filling due to sputum retention (Ogilvie, 1975). Anterior-posterior (inspiration and expiration), right lateral, and right oblique films were taken over a period of 1-2 minutes, starting as soon as filling of the peripheral airways was seen to have occurred (within two to three minutes of completing the injection). Postural drainage was instituted under supervision at the end of the study. No subject with moderate impairment of lung function was studied as an outpatient, and no adverse symptoms resulted from the investigation. One subject developed mild wheezing during bronchography, which responded to a bronchodilator aerosol. Coughing during the procedure was uncommon once satisfactory local anaesthesia had been achieved. There was no association between the occurrence of coughing and the presence of peripheral pooling. The predominant effect of coughing was to clear the airways of contrast material. All films included in the study showed adequate filling of peripheral airways.

At the conclusion of the study an agreed grading of the severity of peripheral pooling was made by a panel of three observers ${ }^{1}$, without knowledge of the clinical, functional, or occupational histories, as 'marked' (Fig. 1), 'moderate', 'minimal' (Fig. 2), or 'absent'.

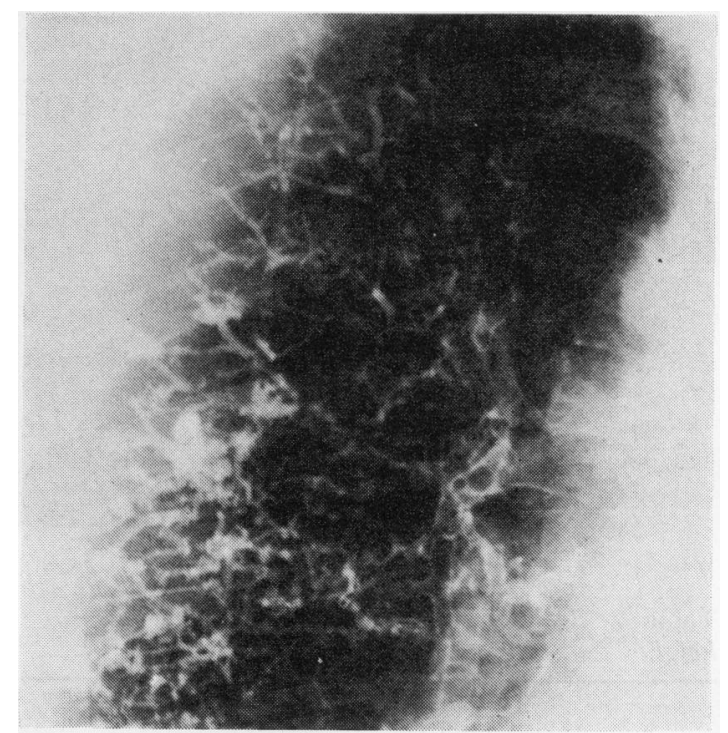

Fig. 1 Bronchogram showing 'spiders' graded as 'marked'.

Preliminary analysis of the results showed the 'minimal' and 'moderate' groups to be indistinguishable by clinical or functional criteria, and they were therefore combined.

Peripheral dye accumulations were further classified according to their resemblance to 'pools' or 'spiders'. At a later reading the bronchographic signs of chronic bronchitis in the larger bronchi of the right lung were noted, the relevant features sought being mucous diverticula, irregularity of the bronchial walls and lumina, and evidence of excess mucus secretion (Gregg and Trapnell, 1969; Ogilvie, 1975).

\section{STATISTICAL METHODS}

Age was related to the presence of peripheral pooling (Table 2). Because the age differences between the groups could account for differences in pulmonary function, adjusted mean values for the bronchographically defined groups were deter-

'Professor Margaret Turner-Warwick, Institute for Diseases of the Chest, London, UK; Professor Bryan Williams, Director of Radiology, The Prince Henry Hospital, Sydney, Australia; Associate Professor Bryan Gandevia, Chairman, Division of Thoracic Medicine, The Prince Henry Hospital, Sydney, Australia 


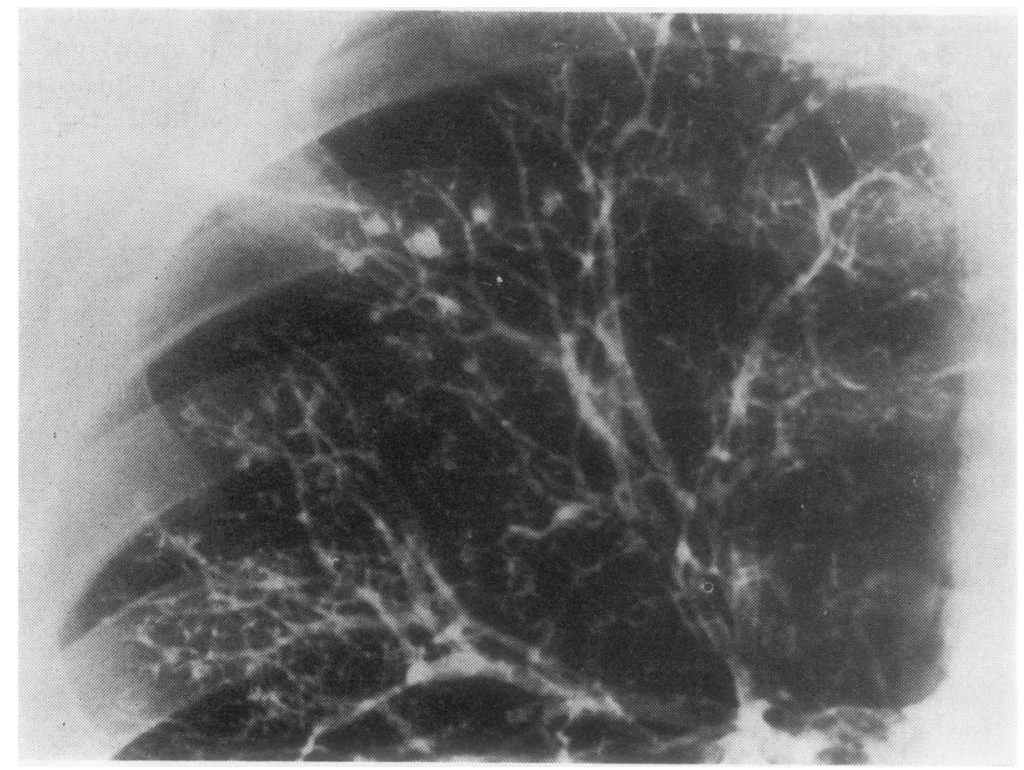

Fig. 2 Bronchogram showin 'pools' graded as 'minimal'. $\mathrm{\omega}_{\omega}$

Table 2 Bronchographic appearance, age, and height

\begin{tabular}{|c|c|c|c|}
\hline & \multicolumn{3}{|l|}{ Pooling } \\
\hline & Absent & $\begin{array}{l}\text { Minimall } \\
\text { moderate }\end{array}$ & Marked \\
\hline $\begin{array}{l}\text { Number of subjects } \\
\text { Mean age (years } \pm 1 \text { SD) } \\
\text { Mean height }\end{array}$ & $\begin{array}{l}33 \\
40 \cdot 2 \div 8 \cdot 5\end{array}$ & $\begin{array}{l}22 \\
46 \cdot 4 \pm 6 \cdot 6^{*}\end{array}$ & $\begin{array}{l}11 \\
54 \cdot 2 \pm 9 \cdot 1^{* *}\end{array}$ \\
\hline (metres $\pm 1 \mathrm{SD})$ & $1.71 \pm 0.08$ & $1.75 \pm 0.05$ & $1 \cdot 70 \pm 0.06$ \\
\hline
\end{tabular}

Statistical significance of difference from group with absent pooling (Student's $t$ test) ${ }^{*} \mathrm{P}<0.05,{ }^{*} \mathrm{P}<0.01$

mined from an analysis of covariance using age and height as covariates (Snedecor and Cochran, 1967). The significance of differences between these adjusted means was established from this analysis.

\section{Results}

Within the group of subjects without pooling, the measurements of pulmonary function did not differ significantly between cigarette smoking categories. The pulmonary function results of non-smokers was therefore combined with those of ex-smokers and current smokers for comparison with the subjects with marked and mild/moderate pooling.

The prevalence of clinical abnormality was higher in subjects with abnormal bronchograms (Table 3). No peripheral pooling was found in the bronchograms of non-smokers. Crackles and a loose cough were significantly more frequent irô, subjects with pools than in those without Smoking was significantly related to the presence? of cough and sputum; only one non-smoker adê mitted to cough and sputum, and only 10 smokers denied cough and sputum $(\mathrm{P}<0.001)$. In this series no association was found between peripheral pools. and the bronchographic signs of chronic bronchitis in larger, more central bronchi.

Table 3 Bronchographic appearance and clinical features

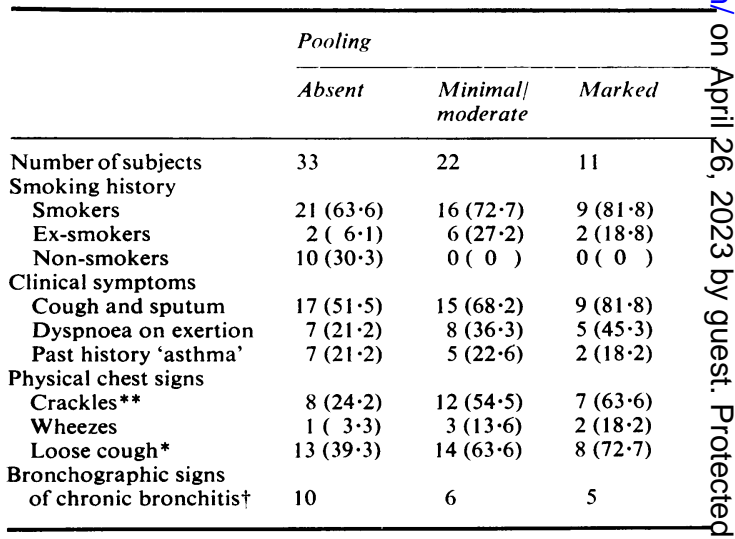

Figures in parentheses are \% column totals.

Statistical significance of differences between bronchographic groups ( $\chi^{2}$ analysis) ${ }^{*} \mathrm{p}<0.05,{ }^{* *} \mathrm{p}<0.01$.

+ Mucous diverticula, irregularity of bronchial walls and luminao excessive mucus secretion in airways. 
Table 4 Peripheral pooling and pulmonary function $\ddagger$

\begin{tabular}{|c|c|c|c|}
\hline & \multicolumn{3}{|l|}{ Pooling } \\
\hline & Absent & $\begin{array}{l}\text { Minimall } \\
\text { moderate }\end{array}$ & Marked \\
\hline Number & 33 & 22 & 11 \\
\hline $\mathrm{FEV}_{1}$ (litres) & $3.24 \pm 0.71$ & $2 \cdot 83 \pm 0.77$ & $2.02 \pm 1.03$ \\
\hline VC (litres) & $4.53 \pm 0.77$ & $4.57 \pm 0.66$ & $4 \cdot 03+1 \cdot 12$ \\
\hline $\mathrm{FEV}_{1} / \mathrm{VC}(\%)$ & $72 \cdot 1 \pm 12 \cdot 6$ & $61 \cdot 6 \pm 12 \cdot 9$ & $47.0 \pm 15 \cdot 8$ \\
\hline $\mathrm{V} \max 50 \% \mathrm{TLC}^{*}$ & $\begin{array}{l}1.92 \pm 1.41 \\
(31)\end{array}$ & $\begin{array}{l}1 \cdot 10 \pm 0 \cdot 76 \\
(18)\end{array}$ & $\begin{array}{l}0.75 \pm 0.54 \\
(6)\end{array}$ \\
\hline $\begin{array}{l}\mathrm{D}_{\mathrm{L}} \mathrm{co}(\mathrm{mmol} / \mathrm{min} / \\
\mathrm{kPa})\end{array}$ & $8 \cdot 9 \pm 1 \cdot 6$ & $8 \cdot 4 \pm 1 \cdot 8$ & $\begin{array}{l}6 \cdot 2 \pm 1 \cdot 2 \\
(9)\end{array}$ \\
\hline TLC (litres) & $\begin{array}{l}6 \cdot 75 \pm 1 \cdot 18 \\
(31)\end{array}$ & $7 \cdot 38 \pm 0.92$ & $7.50 \pm 0.97$ \\
\hline $\mathrm{V}_{\mathrm{L}} 6 \mathrm{~cm} \mathrm{H}_{2} \mathrm{O}$ (litres) & $\begin{array}{l}4 \cdot 32 \pm 1.06 \\
(31)\end{array}$ & $\begin{array}{l}4 \cdot 87 \pm 1 \cdot 16 \\
(21)\end{array}$ & $6.03 \pm 0.99$ \\
\hline $\mathrm{Pstat}_{\mathrm{L}}$ at TLC $(\mathrm{kPa})$ & $\begin{array}{l}3 \cdot 17 \pm 1 \cdot 02 \\
(30)\end{array}$ & $\begin{array}{l}2 \cdot 75 \pm 0.84 \\
(21)\end{array}$ & $1 \cdot 88 \pm 0.42$ \\
\hline $\begin{array}{l}\text { P stat }{ }_{L} \text { at TLC } \\
\text { (relaxed) }(\mathrm{kPa})\end{array}$ & $\begin{array}{l}2 \cdot 23 \pm 0 \cdot 61 \\
(31)\end{array}$ & $\begin{array}{l}2 \cdot 10 \pm 0.54 \\
(21)\end{array}$ & $1 \cdot 40 \pm 0 \cdot 26$ \\
\hline $\mathrm{C}_{\mathrm{L}}$ stat $(1 / \mathrm{kPa})$ & $\begin{array}{l}3.49 \pm 1.55 \\
(31)\end{array}$ & $\begin{array}{l}4 \cdot 06 \pm 1 \cdot 11 \\
(21)\end{array}$ & $5 \cdot 33 \pm 2 \cdot 21$ \\
\hline C closing $(\% \mathrm{TLC}) \dagger$ & $\begin{array}{l}44 \cdot 9 \pm 9 \cdot 2 \\
(30)\end{array}$ & $\begin{array}{l}49 \cdot 2 \pm 8 \cdot 1 \\
(20)\end{array}$ & $\begin{array}{l}57 \cdot 3 \pm 6 \cdot 9 \\
(8)\end{array}$ \\
\hline $\mathrm{R}_{\mathrm{L}}(\mathrm{kPa} / 1 / \mathrm{sec})$ & $\begin{array}{l}0.26 \pm 0 \cdot 16 \\
(31)\end{array}$ & $\begin{array}{l}0 \cdot 29 \pm 0 \cdot 19 \\
(21)\end{array}$ & $\begin{array}{l}0.41 \pm 0.18 \\
(9)\end{array}$ \\
\hline $\mathrm{G}_{\mathrm{s}}(1 / \mathrm{sec} / \mathrm{kPa})$ & $\begin{array}{l}8 \cdot 70 \text { 上 } 3 \cdot 32 \\
(31)\end{array}$ & $\begin{array}{l}7 \cdot 72 \pm 2 \cdot 59 \\
(21)\end{array}$ & $\begin{array}{l}10 \cdot 04 \pm 4 \cdot 36 \\
(9)\end{array}$ \\
\hline $\mathbf{P}_{\mathrm{tm}}(\mathrm{kPa})$ & $\begin{array}{l}0.11 \pm 0.19 \\
(31)\end{array}$ & $\begin{array}{l}0.23 \doteq 0.15 \\
(21)\end{array}$ & $\begin{array}{l}0.17 \pm 0.12 \\
\text { (9) }\end{array}$ \\
\hline
\end{tabular}

Mean values +1 standard deviation. No tests of statistical significance provided because of age differences between the groups.

Figures in parentheses indicate number of subjects tested where this differs from number stated above.

*10 subjects with residual volume $>50 \%$ TLC, ie, zero flow at $50 \%$ TLC excluded.

† 4 subjects with unmeasurable tracing excluded.

†For abbreviations, see methods.

There were significant changes, not explicable in terms of age differences, in the lung function of subjects with peripheral pooling of bronchographic material (Tables 4 and 5); lung function in subjects with mild or moderate pooling was intermediate between those with absent pooling and those with marked pooling. In the presence of peripheral pooling, forced expiratory flow (as reflected by $\mathrm{FEV}_{1}$ and $\mathrm{FEV}_{1} / \mathrm{VC}$ ) was decreased with preservation of vital capacity, closing capacity was raised, lung volume at transpulmonary pressure $6 \mathrm{~cm} \mathrm{H}_{2} \mathrm{O}$ was increased with lower maximum transpulmonary pressures and increased pulmonary compliance, and pulmonary diffusing capacity was reduced. Figure 3 shows the mean static deflation volume-pressure curves for the three groups, together with the mean curves for 10 normal subjects (mean FEV 3.7 1) and 10 subjects with exertional dyspnoea due to pulmonary emphysema (mean $\mathrm{FEV}_{1} 1.31$ ) published by Colebatch et al. (1973). The changes found in subjects with peripheral pooling were in the direction of those found in structural panacinar pulmonary emphysema-loss of pulmonary elastic recoil and diminished pulmonary diffusing capacity but
Table 5 Peripheral pooling and adjusted mean values of pulmonary function $\ddagger$

\begin{tabular}{|c|c|c|c|}
\hline & \multicolumn{3}{|l|}{ Pooling } \\
\hline & Absent & $\begin{array}{l}\text { Minimal/ } \\
\text { moderate }\end{array}$ & Marked \\
\hline $\mathrm{FEV}_{1}$ (litres) & 3.04 & $2 \cdot 85$ & $2 \cdot 51^{*}$ \\
\hline VC (litres) & $4 \cdot 49$ & $4 \cdot 43$ & $4 \cdot 37$ \\
\hline $\mathrm{FEV}_{1} / \mathrm{VC}(\%)$ & $67 \cdot 8$ & $64 \cdot 0$ & $54 \cdot 0 \dagger$ \\
\hline $\mathrm{V} \max 50 \% \mathrm{TLC}(1 / \mathrm{sec})$ & $1 \cdot 71$ & $1 \cdot 23$ & $1 \cdot 30$ \\
\hline $\mathrm{D}_{\mathrm{L}} \mathrm{co}(\mathrm{mmol} / \mathrm{min} / \mathrm{kPa})$ & $8 \cdot 8$ & 8.4 & $6 \cdot 6+$ \\
\hline TLC (litres) & 6.97 & $7 \cdot 07$ & $7 \cdot 42$ \\
\hline $\mathrm{V}_{\mathrm{L}} 6 \mathrm{~cm} \mathrm{H}_{2} \mathrm{O}$ (litres) & $4 \cdot 57$ & $4 \cdot 63$ & $5 \cdot 74$ \\
\hline P stat $\mathrm{L}$ at TLC $(\mathrm{kPa})$ & $3 \cdot 01$ & $2 \cdot 81$ & $2 \cdot 18^{*}$ \\
\hline P stat ${ }_{L}$ at TLC (relaxed) (kPa) & $2 \cdot 11$ & $2 \cdot 11$ & $1 \cdot 71 *$ \\
\hline $\mathrm{C}_{\mathrm{L}}$ stat $(1 / \mathrm{kPa})$ & 3.67 & 3.92 & $5 \cdot 09^{*}$ \\
\hline C closing (\% TLC) & 46.9 & $47 \cdot 7$ & $53 \cdot 9 *$ \\
\hline $\mathbf{R}_{\mathrm{L}}(\mathrm{kPa} / 1 / \mathrm{sec})$ & $0 \cdot 27$ & 0.28 & 0.39 \\
\hline $\mathbf{G}_{\mathbf{8}}(\mathrm{l} / \mathrm{sec} / \mathrm{kPa})$ & $8 \cdot 81$ & $7 \cdot 68$ & $9 \cdot 76$ \\
\hline $\mathbf{P}_{\mathrm{tm}}(\mathrm{kPa})$ & 0.15 & 0.22 & 0.08 \\
\hline
\end{tabular}

Statistical significance of difference from values in group with absent pooling.

${ }^{*} \mathrm{P}<0.05,+\mathrm{P}<0.005$

$\ddagger$ For abbreviations see methods.

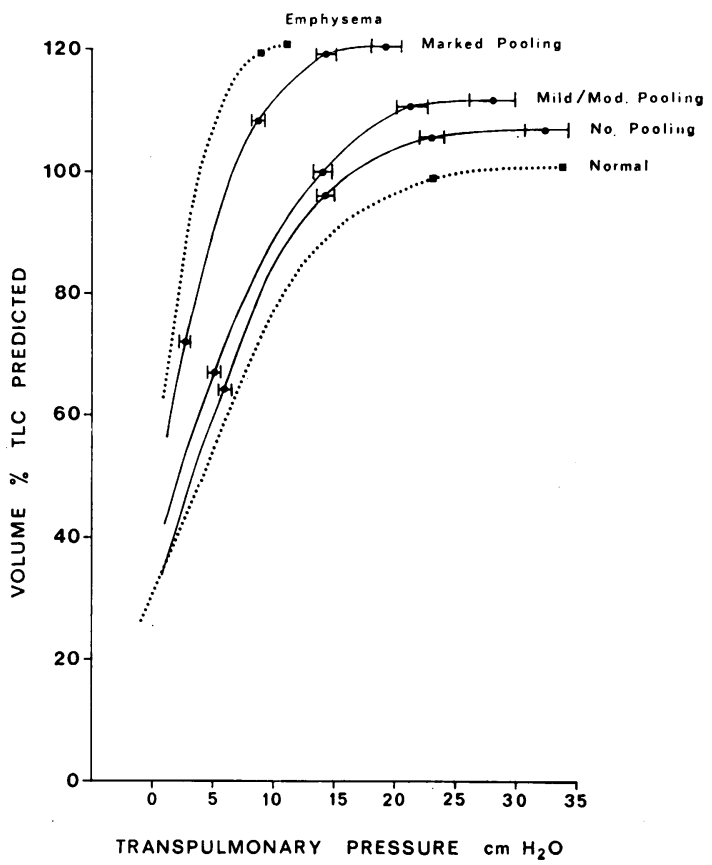

Fig. 3 Mean static deflation volume transpulmonary pressure curves from total lung capacity to residual volume for 11 subjects with marked pooling, 22 subjects with minimal or moderate pooling, and 33 subjects with absent pooling (continuous lines). Interrupted lines are curves for 10 normal subjects and 10 subjects with symptomatic emphysema from Colebatch et al (1973) Horizontal lines show standard error of the mean for each transpulmonary pressure measurement. 
negligible changes in pulmonary resistance or the relationship between maximum expiratory flow and transpulmonary pressure.

Bronchographic differentiation of pools and spiders proved uninformative in that no significant differences emerged between these two groups in terms of clinical or functional criteria. Both appearances were found with equal frequency in all grades of severity and in accordance with the experience of others (Reid, 1955; Freimanis and Molnar, 1960); one-third of the cases could not be classified as showing predominantly one or the other. There was no suggestion that earlier films differed from later films in the proportions of pools and spiders. Reid (1955) suggests a different pathological explanation of these two radiological entities.

\section{Discussion}

It was not considered reasonable in this study to assess the repeatability of the bronchographic appearance of pooling by carrying out a second procedure on any of the subjects. We had to accept the evidence of others (Reid, 1967) that pools represent organic bronchiolar lesions although we recognise that technique may have led to some imprecision in the grading of bronchograms. Similary, it was not the aim of this study to investigate observer variation in the recognition of pooling. It was our impression that the three observers had little disagreement in the grading of the radiographs.

In panacinar pulmonary emphysema the fragmentation of the fibre network of the lung (Wright, 1961) is reflected in a decrease in pulmonary elastic recoil (Colebatch et al., 1973). Alveolar septa are lost and the vascular bed is destroyed (Reid and Heard, 1963), resulting in a decrease in pulmonary diffusing capacity (Bates, 1958; Bedell and Ostiguy, 1967). The demonstration of these functional changes in subjects with peripheral pools indicates that the bronchographic changes correlate with (panacinar) emphysema.

Cigarette smoking in this and other studies (Auerbach et al., 1963; Thurlbeck, 1963; Anderson et al., 1964) is common to the abnormalities demonstrated clinically, physiologically, and radio graphically despite the fact that only one-third of our subjects admitted to dyspnoea on exertion. It appears that pools are not as closely related to disability as to bronchitis clinically and emphysema physiologically. Other studies (Park et al., 1969; Colebatch et al., 1973) in fact suggest that emphysema is not necessarily accompanied by disability, which commonly requires an additional com ponent of bronchial disease.

The absence of a correlation between periphera pools and the bronchographic features of chronie bronchitis in central airways may be a function of our choice of the right upper lobe for bronchow graphic assessment (Ogilvie, 1975) and the relatively mild disability in the present series of subjects; the greater the involvement of proximat airways, the more likely it is that respiratoro disability will be manifest (Park et al., 1969) Alternatively, it may be that there is not necesien sarily a close association between the central anci the peripheral consequences of cigarette smoking $\vec{b}$ that is, between pools and the other generally accepted bronchographic criteria of chronie bronchitis.

The pathological evidence of Reid (1955) indio cates that pooling results from bronchiolitis. obliterans, and an identical bronchographic ap $\overrightarrow{0}$ pearance is seen in the affected lung of unilaterato emphysema in McLeod's syndrome (Reid and Simon, 1962). The association that we have show between pooling and functional changes of panas cinar emphysema supports a causal relationship between bronchiolitis and destruction of tho parenchyma of the lung beyond the bronchiola? abnormality. In the adult subjects we have studie $\Phi$ it appears that the pulmonary overinflation we have shown, which is typical of pulmonary emphysema, is due to collateral ventilation of air. spaces distal to obliterated bronchioles. The observation that overinflation is not usually seept as a result of bronchiolitis in the developing lung of McLeod's syndrome is presumably due to arrested growth of the affected lung. Our results. are compatible with those of Ogilvie (1975), who showed that patients with more frequent pooling have a more rapid rate of clinical deterioration? These studies underline the importance of disease in the small airways in the likely pathogenesis and. progression of chronic obstructive lung diseases, fact for which there is already considerable epidemiological evidence.

We are most grateful to Professor Margaret Turner-Warwick and Professor Bryan Williamf for their assistance in grading the bronchographig appearances, and to Professor H. J. H. Colebatch and Dr. Geoffrey Field for advice in the prepara tion of this report and for their contribution to the laboratory investigation. Our thanks are due alsf to Dr. R. Williams for performing some of the bronchograms and to Dr. V. Kalyanasundaram? Mr. P. Owen, Mrs. R. Tester, and Mrs. Elizabetlg Khoo for technical and clerical assistance. 
We are grateful to Dr. Lynne Reid for reviewing the manuscript.

Grants in support of occupational research by the Division of Thoracic Medicine have been provided by the Workers' Compensation (Dust Diseases) Board of New South Wales, the Australian Tobacco Research Foundation, the National Health and Medical Research Council, and by industry.

Illustrations were prepared by the Department of Medical Illustration, University of New South Wales.

\section{References}

Anderson, A. E., Hernandez, J. A., Eckert, P., and Foraker, A. G. (1964). Emphysema in lung macrosections correlated with smoking habits. Science, 144, 1025-1026.

Anthonisen, N. R., Danson, J., Robertson, P. C., and Ross, W. R. D. (1969-70). Airway closure as a function of age. Respiration Physiology, 8, 58-65.

Auerbach, O., Stout, A. P., Hammond, E. C., and Garfinkel, L. (1963). Smoking habits and age in relation to pulmonary changes. New England Journal of Medicine, 269, 1045-1054.

Bates, D. V. (1958). The measurement of the pulmonary diffusing capacity in the presence of lung disease. Journal of Clinical Investigation, 37, 591605.

Bedell, C. N., and Ostiguy, G. L. (1967). Transfer factor for carbon monoxide in patients with airways obstruction. Clinical Science, 32, 239-248.

Blumenthal, B. J., and Greenberg, S. D. (1972). Alveolobronchography: A new clinical technic in the diagnosis of emphysema. Southern Medical Journal, 65, 905-911.

Christopherson, J. B. (1933). The anatomy of chronic bronchitis and bronchial asthma as disclosed by lipiodol examination. American Journal of the Medical Sciences, 186, 504-509.

Colebatch, H. J. H., Finucane, K. E., and Smith, M. M. (1973). Pulmonary conductance and elastic recoil relationships in asthma and emphysema. Journal of Applied Physiology, 34, 143-153.

Cotes, J. E. (1958). Lung Function, 2nd edition, p. 245. Blackwell: Oxford.

Duinker, N. W., and Huizinga, E. (1962). The 'flowers' in bronchography. Thorax, 17, 175-178.

Freimanis. A. K., and Molnar, W. (1960). Chronic bronchitis and emphysema at bronchography. Radiology, 74, 194-205.

Gamsu, G., and Nadel, J. A. (1973). The roentgenologic manifestations of emphysema and chronic bronchitis. Medical Clinics of North America, 57, $719-733$.

Gregg, I., and Trapnell, D. H. (1969). The bronchographic appearance of early chronic bronchitis. British Journal of Radiology, 42, 132-139.

Hall, G., and Gandevia, B. (1971). Relationship of the loose cough sign to daily sputum volume. British Journal of Preventive and Social Medicine, 25, 109. 113.

Heard, B. E. (1969). Pathology of Chronic Bronchitis and Emphysema, Chapter 14. Churchill: London.

Leaver, D. G., Tattersfield, A. E., and Pride, N. B. (1973). Contributions of loss of lung recoil and of enhanced airways collapsibility to the air flow obstruction of chronic bronchitis and emphysema. Journal of Clinical Investigation, 52, 2117-2128.

Leopold, J. G., and Gough, J. (1963). Postmortem bronchography in the study of bronchitis and emphysema. Thorax, 18, 172-177.

Leopold, J. G., and Seal, R. M. (1961). The bronchographic appearance of 'peripheral pooling' attributed to the filling of centrilobular emphysematous spaces. Thorax, 16, 70-77.

Mead, J. (1960). Volume displacement body plethysmograph for respiratory measurements in human subjects. Journal of Applied Physiology, 15, 736740.

Mead, J., and Whittenberger, J. L. (1952-53). Physical properties of human lungs measured during spontaneous respiration. Journal of Applied Physiology, 5, 779-796.

Milic-Emili, J., Mead, J., Turner, J. M., and Glauser, E. M. (1964a). Improved technique for estimating pleural pressure from esophageal balloons. Journal of Applied Physiology, 19, 207-211.

Milic-Emili, J., Mead, J., and Turner, J. M. (1964b). Topography of esophageal pressure as a function of posture in man. Journal of Applied Physiology, 19, 212-216.

Nakamura, T., Takizawa, T., Takishima, T., Konno, K., Hoshino, F., Kurashina, T., and Hatayama, T. (1969). Selective alveolo-bronchography in chronic pulmonary emphysema. Tohoku Journal of Experimental Medicine, 99, 207-215.

Ogilvie, A. G. (1975). Bronchography in chronic bronchitis. Thorax, 30, 631-635.

Ogilvie, C. M., Forster, R. E., Blakemore, W. S., and Morton, J. W. (1957). A standardized breath holding technique for the clinical measurement of the diffusing capacity of the lung for carbon monoxide. Journal of Clinical Investigation, 36, 1-17.

Park, S. S., Yoo, O. H., Janis, M., and Williams, M. H. (1969). Postmortem evaluation of air flow limitation in obstructive lung disease. Journal of Applied Physiology, 27, 308-312.

Reid, J. A., and Heard, B. E. (1963). The capillary network of normal and emphysematous lungs studied by injection of Indian ink. Thorax, 18, 201-212.

Reid, Lynne (1955). Correlation of certain bronchographic abnormalities seen in chronic bronchitis with the pathological changes. Thorax, 10, 199-204.

Reid, Lynne (1967). The Pathology of Emphysema, pp. 124-126. Lloyd-Luke: London.

Reid, Lynne, and Simon, G. (1962). Unilateral lung transradiancy. Thorax, 17, 230-239.

Reid, Lynne, and Simon, G. (1959). Pathological findings and radiological changes in chronic bronchitis 
and emphysema. British Journal of Radiology, 32, 291-305.

Simon, G. (1958). Radiological Appearances. In Recent Trends in Chronic Bronchitis, edited by N. C. Oswald, pp. 63-87. Lloyd-Luke: London.

Simon, G., and Galbraith, H. J. B. (1953). Radiology of chronic bronchitis. Lancet, 2, 850-852.

Simonsson, B. G. (1965). Clinical and physiological studies on chronic bronchitis. Acta Allergologica, 20, 257-324.

Snedecor, G. W., and Cochran, W. G. (1967). Statistical Methods, 6th edition. Ames, Iowa State University Press.

Thurlbeck, W. M. (1963). A clinico-pathological study of emphysema in an American hospital. Thorax, 18, 59-67.
Thurlbeck, W. M. (1976). Chronic Airflow Obstruc- $\overrightarrow{\vec{N}}$ tion in Lung Disease, p. 418. Saunders: Philadelphia.

Virgulto, J., and Bouhuys, A. (1973). Electronic circuits for recording of maximum expiratory flowvolume (MEFV) curves. Journal of Applied $\stackrel{\text { }}{\vec{\circ}}$ Physiology, 35, 145-147.

Wisoff, C. P. (1958). Bronchiolectasis in chronic bronchitis. Radiology, 70, 848-850.

Wright, R. R. (1961). Elastic tissue of normal and $\vec{\circ}$ emphysematous lungs. American Journal of $\overrightarrow{\vec{H}}$ Pathology, 39, 355-363.

Requests for reprints to: Associate Professor Bryan $\omega_{\omega}^{\dot{\omega}}$ Gandevia, The Prince Henry Hospital, Little Bay, î 2036, New South Wales, Australia. 